\title{
Investigation of the External High and Moderate Water Pressure Influence on the Properties of the Sealed Thermoplastic Assembly Parts
}

\author{
Jovan Radulović ${ }^{1)}$ \\ Duško Knežević ${ }^{1)}$
}

\begin{abstract}
In this paper the influence of the external high and moderate water pressure on the properties of the sealed thermoplastic assembly parts are described. The specimen made of the impact resistant polystyrene mark Styron 485 , four sealing systems and indicator paper (placed inside the sealed parts) are used for the production of the mentioned assemblies. Specific white silicone mark Dow Corning, modified black silicone mark Permatex, encapsulating system mark Araldite consisting of a modified epoxy resin and amine hardener and the solution obtained by dissolving the polystyrene mark Styron 485 in toluene, are used. The produced assemblies were sink in the water at the depth of $4 \mathbf{m}$ (high water pressure) and at the depth of $1 \mathrm{~m}$ (moderate water pressure) according to the SRPS EN 60068-2-17 standard. Based on the detailed inspection of the plastic parts in the assemblies and indicator paper, it was concluded that the water breakthrough did not happen and that all four applied systems prevented the water pass through the sealed assemblies. The tensile testing of the produced assemblies was done in order to establish a homogeneity of the used sealing systems in the mentioned assemblies. Based on the visual inspection it was concluded that white silicone (system 1), black silicone (system 2) and epoxy system (system 3) are homogenous in the produced joints, while at the joints with a polystyrene solution (system 4) a certain porosity is recorded.
\end{abstract}

Key words: plastic materials, construction elements, assembly, water pressure, sealants, assembly homogeneity.

\section{Introduction}

$\mathrm{O}$ $\mathrm{NE}$ of the essential elements of the complex construction is a regular functioning i.e. acting of the assemblies built in the final product.

The assemblies can be exposed to very diverse influences.

Generally speaking, for a production of the assembly elements, different materials can be used (polymeric materials, metal materials, wood, ceramic, glass, etc.), but in this paper, the elements made of plastic material would be discussed.

It has been estimated, at the beginning of this century, that about five million people are employed in the plastic industry in the world [1].
The assembly elements can be jointed in different ways, in order for the produced assembly to fulfill its function.

\section{Sealed plastic assemblies}

Plastics materials, generally speaking, can be divided into thermoplastic and thermosetting materials.

Both types of materials are used for a high-volume or lowvolume production.

Procedures for the assemblies production for the above mentioned materials and volume levels are presented in Table 1 [1].

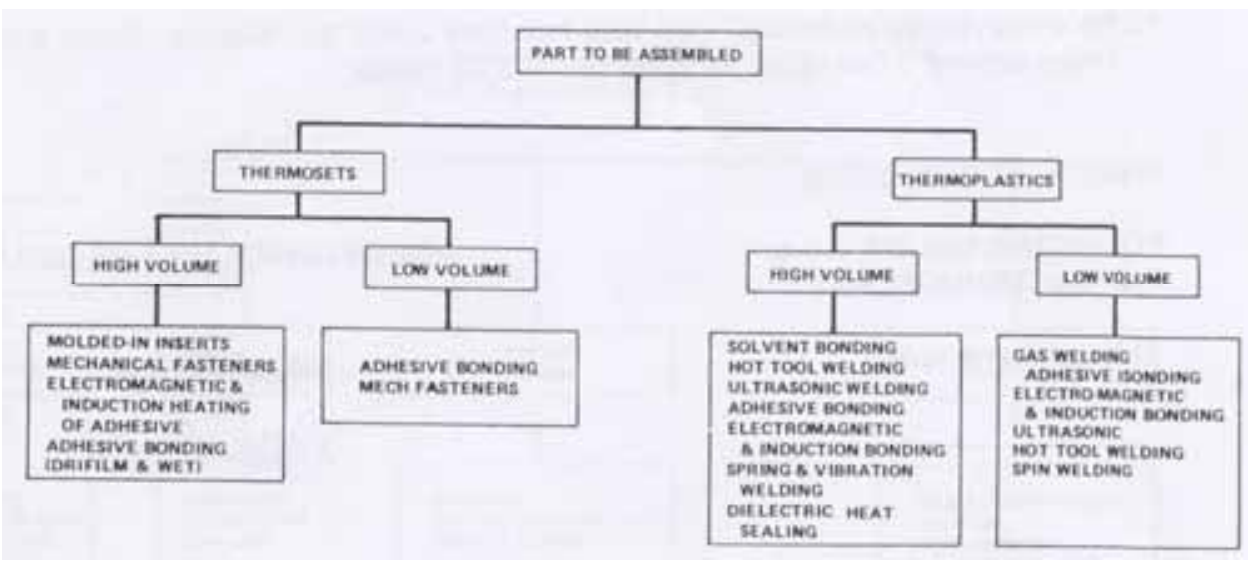

Table 1. Procedures for the assemblies production

\footnotetext{
1) Military Technical Institute (VTI), Ratka Resanovića 1, 11132 Belgrade, SERBIA

Correspondence to: Duško Knežević; e-mail: dus.knez@sbb.rs
} 
This paper comprises an investigation of the external high and moderate water pressure influence on the sealed thermoplastic assembly parts' properties.

Sealant material is a material in paste and liquid form that is applied to all types of joints, and that cures and forms a seal against water, gases and outdoor factors [1].

As it can be seen from Table 1, the sealing is one of the rational procedures for the assemblies production when thermoplastic high-volume parts are concerned.

Generally speaking, there are two types of sealant materials: hardening and non-hardening.

The hardening types can be further classified as rigid or flexible.

Rigid, hardening types set up firm and have little or no resiliency, whereas flexible, hardening sealant remain flexible after the cure.

Non-hardening sealants remain wet and flexible after the application and never truly dry [2].

Major sealants are based on silicone, epoxy resins, butyl elastomers, polychloroprene, polysulphide-polyether polymers, polyurethanes, high sulphur liquid polymers and aqueous- and solvent-based acrylates.

In this paper the main and important facts concerning a non-standard problem are described. Opposite to the relatively well known and detailed described technical solutions of the sealing assemblies, as e.g. plastic vessels used for pharmaceutical and food industry [3], or glass sealed vessels for cooking food [4], the existing problem is how to seal the thermoplastic parts assemblies which are exposed to the influence of the external high and moderate water pressure.

This paper presents details regarding the thermoplastic material parts, four used sealing systems, procedures for the assemblies production and the results obtained by testing the mentioned assemblies after the influence of the external high and moderate water pressure.

\section{Materials used}

Elements of the assemblies, intended for the investigation of the external high and moderate water pressure influence on the properties of the sealed thermoplastic assembly parts, are produced by the injection molding of a high-impact polystyrene.

The injection molding is the most important molding method for the thermoplastic materials $[5,6]$.

Although polystyrene is not an engineering thermoplastic material, it is intensively used for fabrication products which find application in numerous areas of human activities.

Polystyrene is obtained by a free-radicals initiated chain polymerization of styrene and its basic unit in a macromolecule chain is shown in Fig.1.

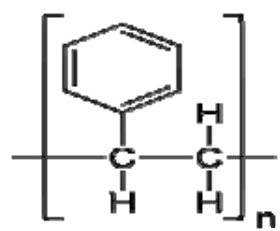

Figure 1. Polystyrene basic unit

The main properties of polystyrene are rigidity, good electrical insulation characteristics, no taste, no odor or toxicity, low water absorption, transparency, ease of color and processing, very low cost, but the limitation is its brittleness.
By adding a styrenbutadiene rubber to polystyrene this problem is solved and a high-impact polystyrene is produced.

Silicone materials, system epoxy resin and solvent based polystyrene are chosen as the sealant materials for the purpose of this paper.

All chosen sealant systems are room temperature curing i.e. vulcanizing.

The chemist Frederick Kipping pioneered the study of the organic compounds of silicon (organosilicons) and coined the term "silicone"[7].

Silicones, more precisely named polymerized siloxanes or polysiloxanes, are mixed inorganic-organic polymers with the chemical formula $\left[\mathrm{R}_{2} \mathrm{SiO}\right]_{n}$, where $\mathrm{R}$ is an organic group such as methyl, ethyl, or phenyl. These materials consist of an inorganic silicon-oxygen backbone ( $\cdots$-Si-OSi-O-Si-O-...) with the organic side groups attached to the silicon atoms, which are four-coordinate.

Silicone is produced by polycondensation of chlorosilane and its basic unit is shown in Fig. 2 .

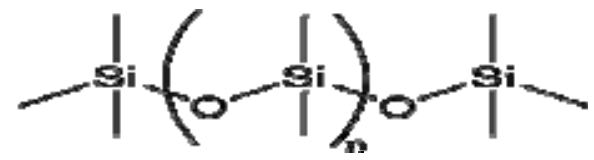

Figure 2. Silicone basic unit

Polymers in which a main chain is consisting of repeating -Si-O-units together with predominantly organic side groups are referred to as polyorganosiloxanes, or loosely silicones.

These materials are by far the most important inorganic polymers and are based on silicone, a transient metal abundantly available on our planet.

Silicone polymers are available on a number of forms: fluids, paste, grease, rubber and resins.

Owing to their general thermal stability, water repellency, anti-adhesive characteristics and constancy of properties over a wide temperature range, silicones have found numerous and diverse applications [2].

Practically, there are "one component" and "twocomponent" silicones.

"One component" room-temperature vulcanizing (RTV) silicone consists of an air-tight package containing silanolterminated polysiloxane, cross linking agent (metyl acetoxy silane) and catalyst (e.g. dibytiltin laurate).

The moisture from the atmosphere converts the crosslinking agent to the corresponding silanol, which brings about further polymerization combined with the crosslinking of polysiloxane.

In case of the "two-component" RTV silicone, the polysiloxane and cross-linking agent are in the separate packages. A typical "two-component" RTV formulation cures by the reaction of silanol end groups with silicate ester in the presence of catalyst.

Epoxy resins are oligomeric compound with the threemembered oxirane (epoxy) groups. Reaction product of bisphenol A and epichlorohydrin, whose structure is shown in Fig.3, comprise about $90 \%$ of the world's production of this thermosetting material.

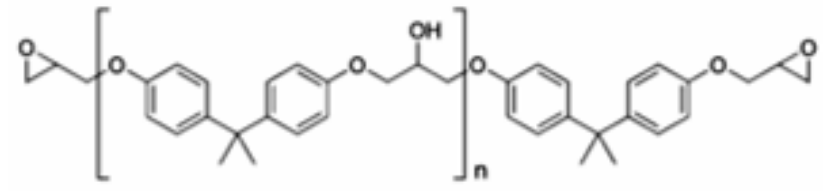

Figure 3. Reaction product of bisphenol A and epichlorohydrin 
Standard epoxy resins with $0,1<\mathrm{n}<0,6$ are liquid, while those with $2<\mathrm{n}<25$ are solid [8].

Epoxy resins are hardened (cured) by the cross-linking reaction of their oxirane and hydroxyl groups with polyfunctional amines (cold curing) and acid anhydrides (warm curing). Cold curing generates $\beta$-hydroxy propylamine structures, for example $\mathrm{R}^{\prime} \mathrm{R}^{\prime} \mathrm{N}-\mathrm{CH}_{2}-\mathrm{CHOO}-$ $\mathrm{CH}_{2}$ from $\mathrm{R}$ ' $\mathrm{R}$ ' $\mathrm{NH}$ and epoxy groups and correspondingly from polyfunctional amine (here used triethylenetetramine presented in Fig.4, diethylenediamine, etc).

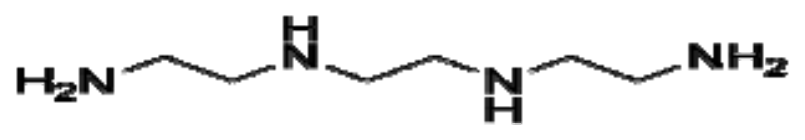

Figure 4. Triethylenetetramine

Warm curing leads to the ester structure from epoxy and hydroxyl groups and the ether structure from epoxy group. The main advantages of the epoxy sealants are their high degree of adhesion, low cost, easy handling, high cohesive strength, low shrinkage and good overall chemical resistance.

Dilute-polystyrene solution is obtained by dissolving polystyrene, which is used for the production of the assembly elements i.e. upper and lower parts, in toluene.

Polystyrene [by IUPAC nomenclature poly(1phenylethylene)] is an aromatic polymer.

Toluene (by IUPAC nomenclature methylbenzene), whose formula is shown in Fig.5, is an aromatic derivative of benzene, non-miscible with water.

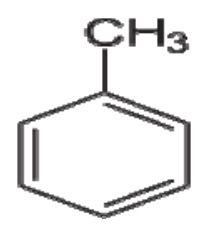

Figure 5. Toluene

Basic point for this procedure is so called "similar to similar" principle. Sealing of polystyrene parts with the solution of polystyrene in an appropriate solvent is, in free speech," cold welding".

Water has the unique physical characteristics and such a chemical reactivity that it is an important factor in the deterioration process of organic and of course polymeric materials [9].

Water is the life blood of a human body because it makes up $70 \%$ of who we are, yet in excess it may kill us. There is a statement that the root of all evil is water. It dissolves buildings. Water is the elixir to unwelcome organisms such as rats and insects. Water, the universal solvent, makes chemical reactions happen every place one does not want them. It consumes wood, erodes masonry, corrodes metals, peels paint, expands destructively when it freezes, and permeates everywhere when it evaporates. It warps, swells, discolours, rusts, loosens, mildews and stinks [10].

An indicator paper mark pH 1-14, Q/GHSC 1544-1999 produced by Shanghais SSS Reagent, Co. Ltd was used.

\section{Experimental part}

Plastics parts were obtained by the technology of injection molded polystyrene of Styron 485 trade mark, produced by Dow Chemicals Company, USA [11].

Polystyrene was discovered in 1839 by Eduard Simon, and the first industrial production started in 1931 in I.G.Farben company, Ludwigshafen, Germany. This easyflow polystyrene is characterized by a high impact resistance and good flexibility. An upper and lower plastic parts, shown in Figures 6 and 7, respectively, are used for the assemblies production, intended for the sealing investigation.

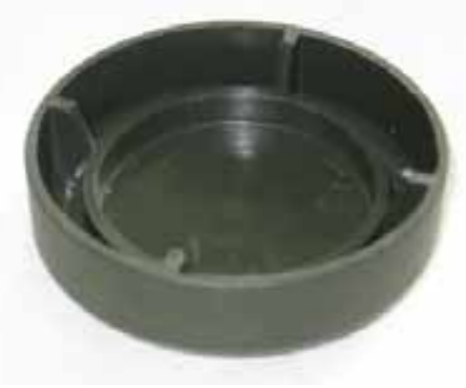

Figure 6. Upper part of the assembly

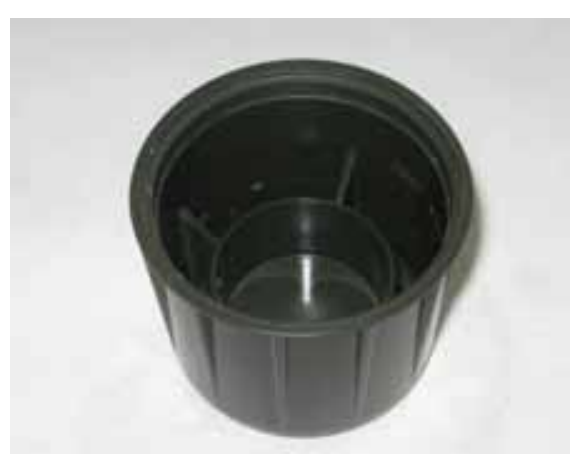

Figure 7. Lower part of the assembly

For the sealing of the assembly, which consists of mentioned upper and lower parts, the four sealing systems are used:

1. System 1 is a specific white silicone of Dow Corning 744 trade mark, produced by Dow Corning Company, USA. This one-component RTV silicone has a good adhesion to many different materials and is stable and neutral from $-50^{\circ} \mathrm{C}$ to $+180^{\circ} \mathrm{C}$. It realizes the sealed joint resistant to mechanical shocks, temperature cycling and outdoor influences (water, moisture, mechanical action, etc.) [12].

2. System 2 is a black modified silicone of Permatex Black Silicone Adhesive Sealant trade mark, produced by Permatex, USA. It is one-component sealant for plastics, metal, glass surface, resistant to water, vibrations and used from $-59^{\circ} \mathrm{C}$ to $232^{\circ} \mathrm{C}$ [13].

3. System 3 is an epoxy system, which consists of the epoxy resin of Araldite DBF trade mark and hardener of Hearter 951 trade mark, both produced by Huntsman, USA. This is a low-viscous system with good mechanical properties, excellent electrical characteristics and good resistance to the weather influences, which cure at room temperature. Epoxy resin Araldite DBF is a liquid reaction product of bisphenol $\mathrm{A}$ and of epichlorohydrin, of the average molecular weight $<700$.

Curing agent Haerter 951 is a liquid polyfunctional polyamine i.e. triethylenetetramin (by IUPAC nomenclature $\mathrm{N}^{\prime}$-[2-(2-aminiethylamino)ethyl]ethan1,2-diamine) [14].

4. System 4 is a solution of polystyrene of Styron 485 trade mark in toluene, which is produced by Hemrad, Serbia.

The system 4 is obtained by dissolving $30 \mathrm{~g}$ of polystyrene in $70 \mathrm{~g}$ toluene with gentle warming. 
In order to achieve the best results in sealing, also in bonding, it is necessary to prepare the working surfaces in a regular manner.

The strength of the realized joint, in great extent, depends on an adhesion between the working surfaces and applied material.

The adhesion forces between sealant and working surfaces are improved, to an important extent, by removing a surface layer of an appropriate material in a mechanical manner and by degreasing and cleaning with the appropriate chemicals.

The surface layers of polystyrene upper and lower parts are removed by the abrasive paper, followed by ethanol degreasing and cleaning.

In order to check the efficiency of the applied treatment (mechanical removing, degreasing and cleaning) a "water drop method" can be used.

A few drops of clean water are put on the prepared surfaces. If water drops remain ball shape, the surface is not clean enough. If water drops spread out over the surface, the wetting of surface is good and the surface is clean enough [15].

Internal surface of the lower part is properly dried, an indicator paper is put into the lower part, the upper part is positioned on the lower part and the gap between lower and upper part is sealed with the chosen sealing system.

The first group of the assemblies is exposed to a high water pressure in the metal tube because the sealed assemblies are immersed at the depth of $4 \mathrm{~m}$ for the period of $24 \mathrm{~h}$ into the water temperature of $23^{\circ} \mathrm{C}$ according to the paragraphs 5.5.2. (depth of immersion), 5.5.3. (period of immersion) and 5.5.4. (temperature of water) of the SRPS EN 60068-2-17 standard [16].

The second group of the plastic assemblies is exposed to the moderate water pressure in the metal tube because the assemblies are immersed at the depth of $1 \mathrm{~m}$ for the period of $24 \mathrm{~h}$ in the water temperature of $23^{\circ} \mathrm{C}$, according to the mentioned paragraphs of the above noted standard.

For the purpose of this paper a mark system/depth is introduced. For example, the mark $3 / 4$ denotes the assembly sealed with the system 3 (epoxy system) and immersed in water to the depth of $4 \mathrm{~m}$.

\section{Results of testing and analysis}

The plastic assemblies' marks $1 / 1,2 / 1,3 / 1$ and 4/1, i.e. the assemblies sealed with the systems 1 (white silicone), 2 (black silicone), 3 (epoxy resin) and 4 (polystyrene solution) after the immersion at the depth of $1 \mathrm{~m}$ (moderate water pressure) are presented in Figures 8-11, respectively [17].

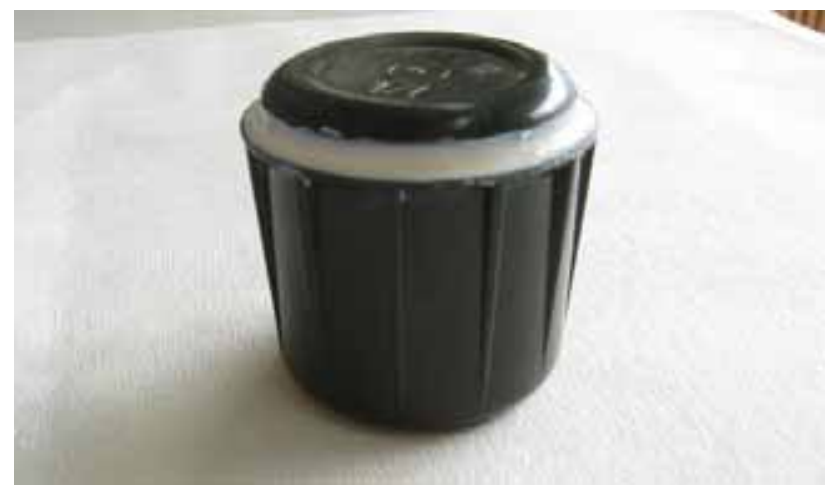

Figure 8. Assembly mark 1/1(sealed with white silicone)

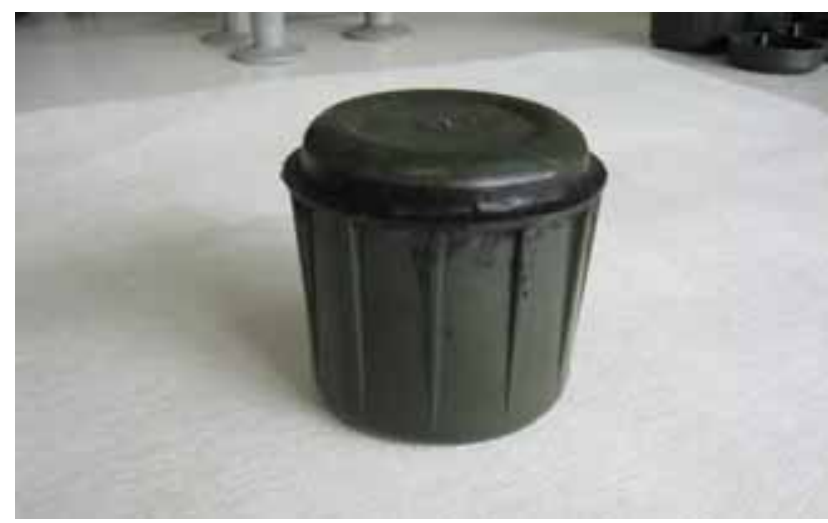

Figure 9. Assembly mark 2/1 (sealed with black silicone)

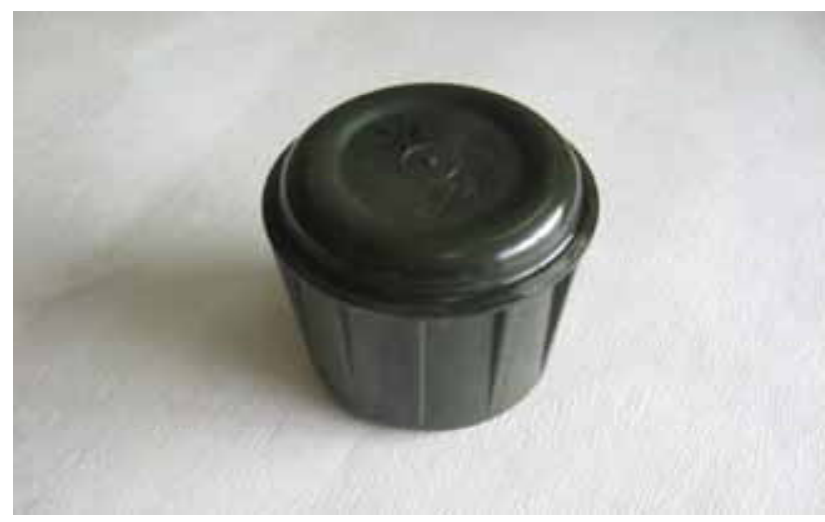

Figure 10. Assembly mark 3/1 (sealed with epoxy resin)

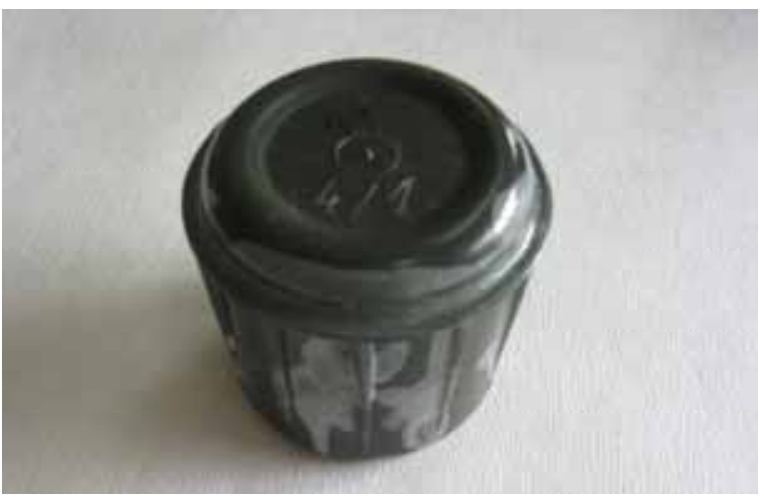

Figure 11. Assembly mark 4/1 (sealed with polystyrene solution)

By the visual inspection of the assemblies' marks $1 / 1$, $2 / 1,3 / 1$ and $4 / 1$ no changes are recorded on the sealing materials.

The mentioned assemblies are carefully cut in a horizontal direction. In case of the indicator paper, which is in the lower part of assemblies, no change is recorded at the tested specimen. A detailed examination of the internal surfaces of the lower and upper parts is done and no traces of water are recorded.

The plastic assemblies' marks $1 / 4,2 / 4,3 / 4$ and 4/4, i.e. the assemblies sealed with the systems 1, 2, 3 and 4, after the exposure to a high water pressure (the immersion depth of $4 \mathrm{~m}$ ), are carefully examined. By the visual inspection of the mentioned assemblies no changes are recorded on the sealing materials, excluding few stains, at the couple of specimen, owing to the corrosion of the metal tube, in which the assemblies were immersed.

The mentioned assemblies are carefully cut in a horizontal direction and shown in Figures 12-15, respectively. 


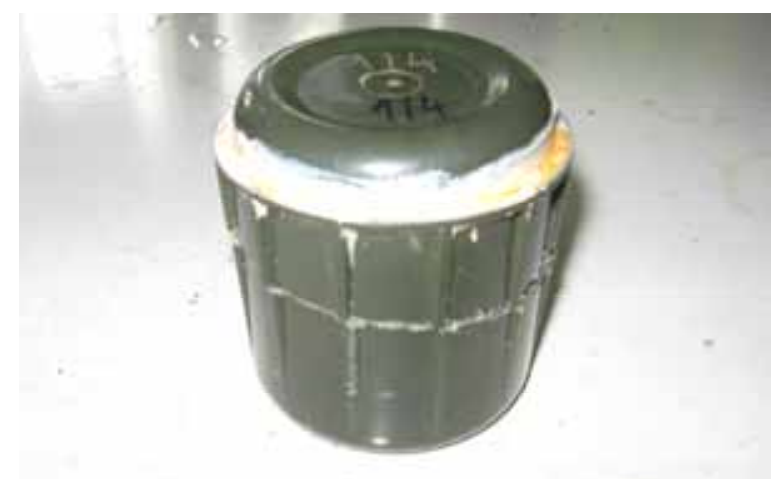

Figure 12. Assembly mark $1 / 4$

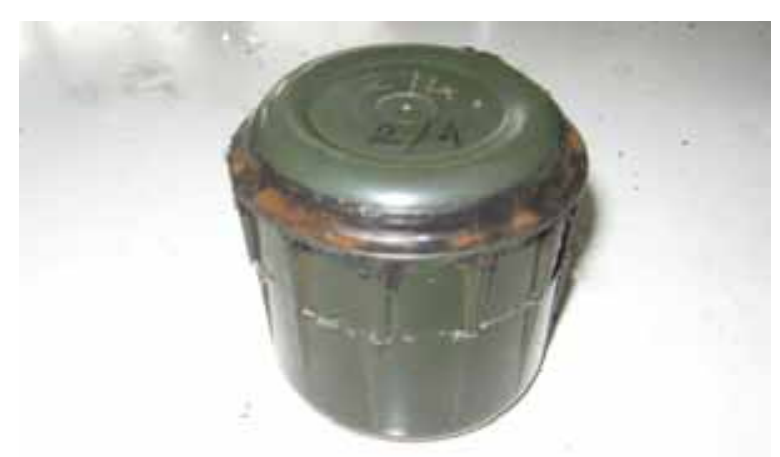

Figure 13. Assembly mark $2 / 4$

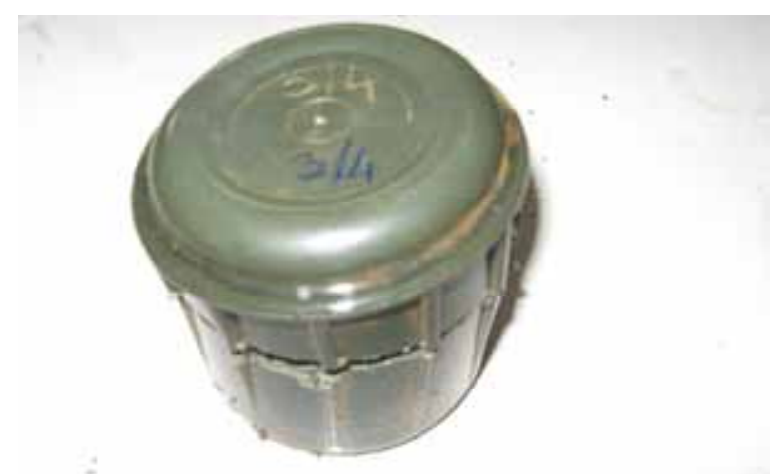

Figure 14. Assembly mark $3 / 4$

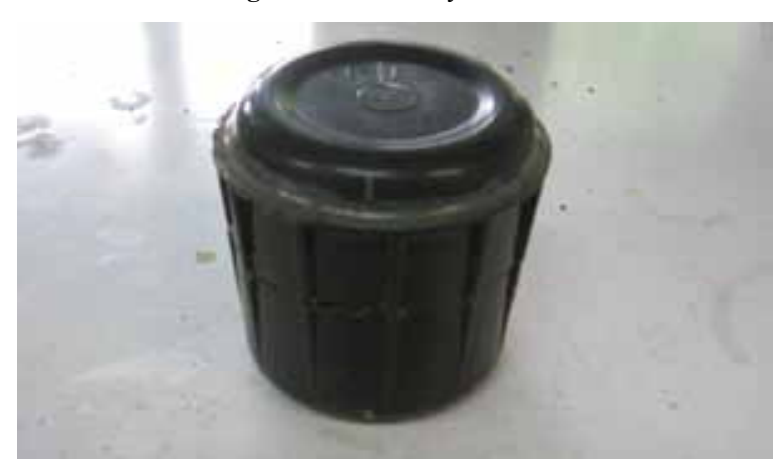

Figure 15. Assembly mark 4/4

In case of the indicator paper, which is in the lower part of the assemblies, no change is recorded at no one the tested specimen. Internal surfaces of the lower and upper parts are carefully examined and no traces of water are recorded.

In order to establish a homogeneity of the sealing material in the realized joints, the assemblies' marks $1 / 4$, $2 / 4,3 / 4$ and $4 / 4$ are cut in a vertical direction.

Cross-sections of the assemblies, sealed by the systems $1,2,3$ and 4, after the immersion in water at the depth of 4 $\mathrm{m}$, are shown in Figures 16-19, respectively.

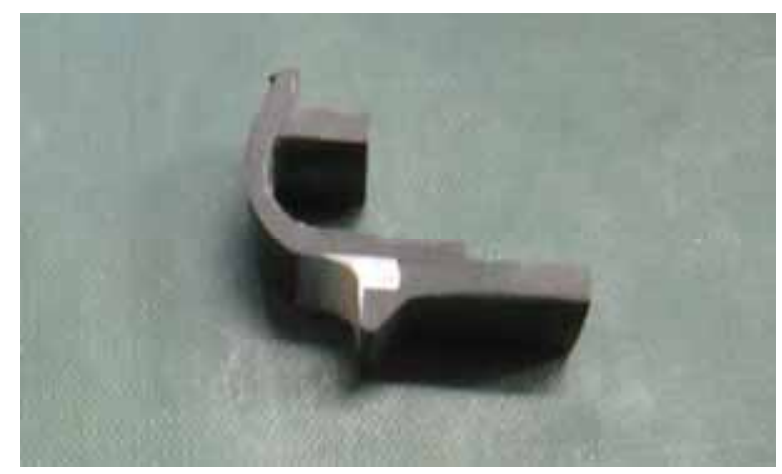

Figure 16. Cross-section of the assembly mark 1/4 (sealed with the system 1)

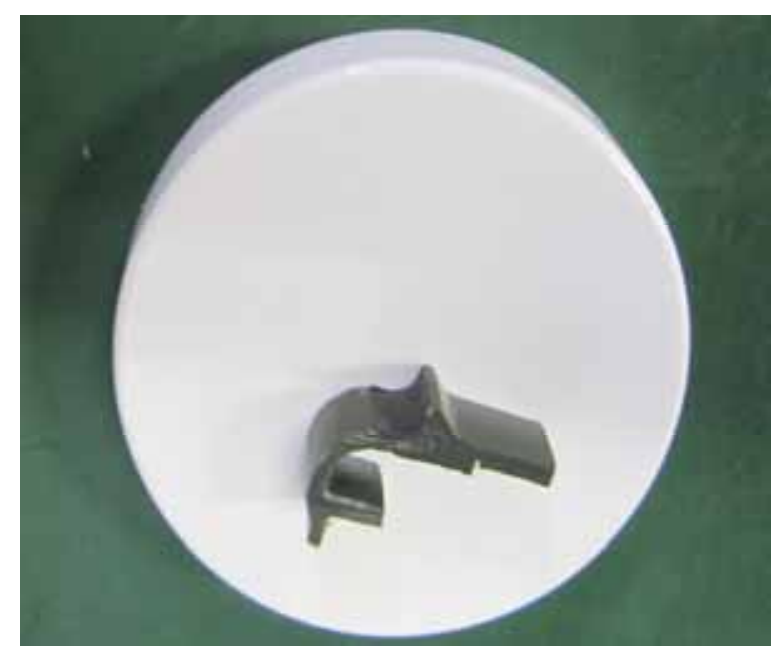

Figure 17. Cross-section of the assembly mark $2 / 4$ (sealed with the system 2 )

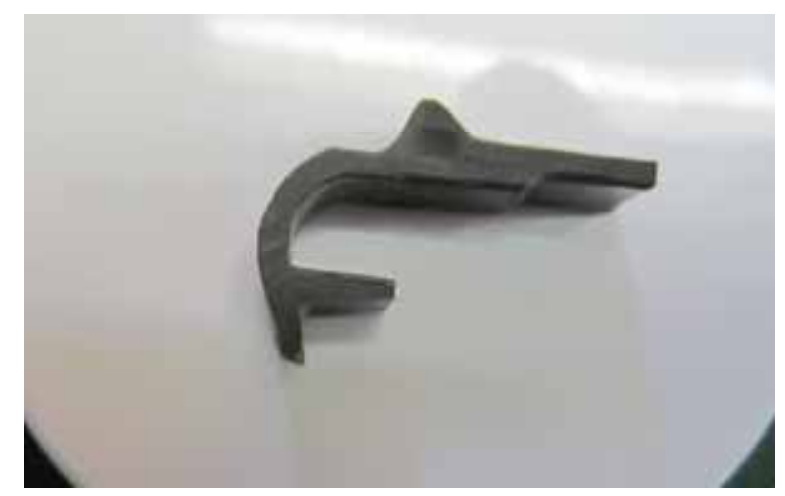

Figure 18. Cross-section of the assembly mark 3/4 (sealed with the system 3 )

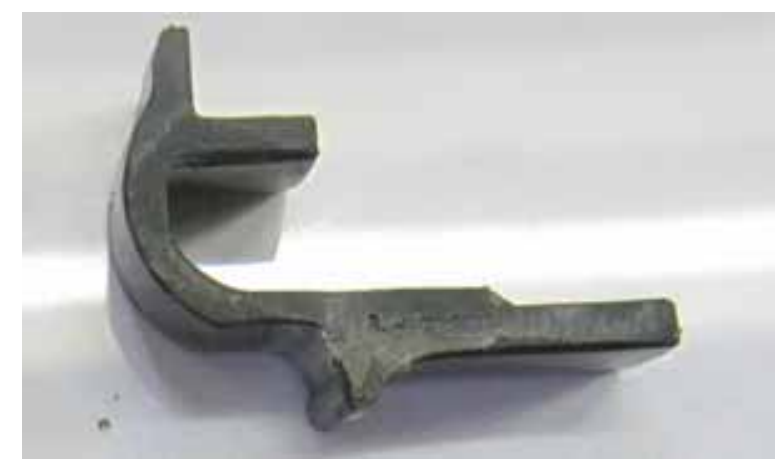

Figure 19. Cross-section of the assembly mark 4/4 (sealed with the system 4)

The complete homogeneity of the system 1 (white silicone), system 2 (black silicone) and system 3 (epoxy resin) is established by a detailed visual examination, while in the system 4 (polystyrene solution) a certain porosity is recorded. 
Specimens, cut out from the assembly sealed with all four systems, are exposed to a tensile stress. A scheme of a device, used for tensile testing, is presented in Fig.20.

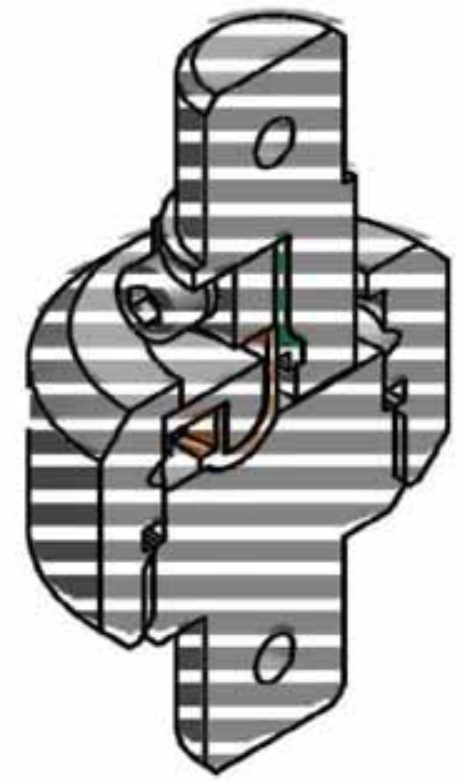

Figure 20. Scheme of a device used for tensile testing

Specimen obtained by the tensile investigation are shown in Figures 21-24, respectively.

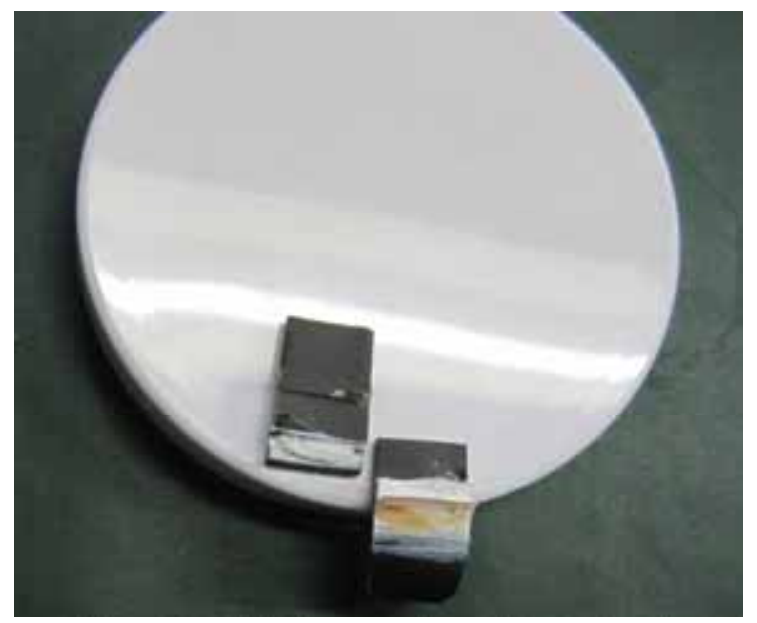

Figure 21. Parts of the specimen cut out from the assembly sealed with the system 1 , after tensile testing

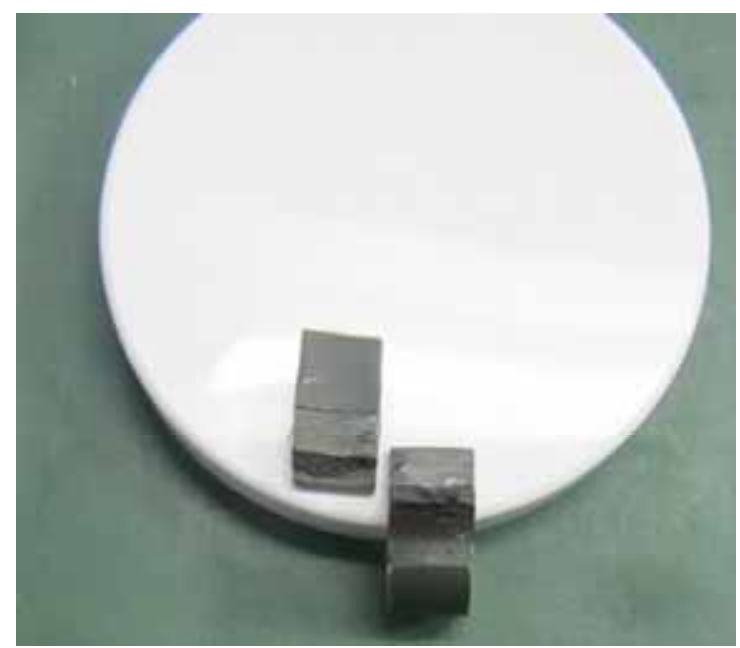

Figure 22. Parts of the specimen cut out from the assembly sealed with the system 2 , after tensile testing

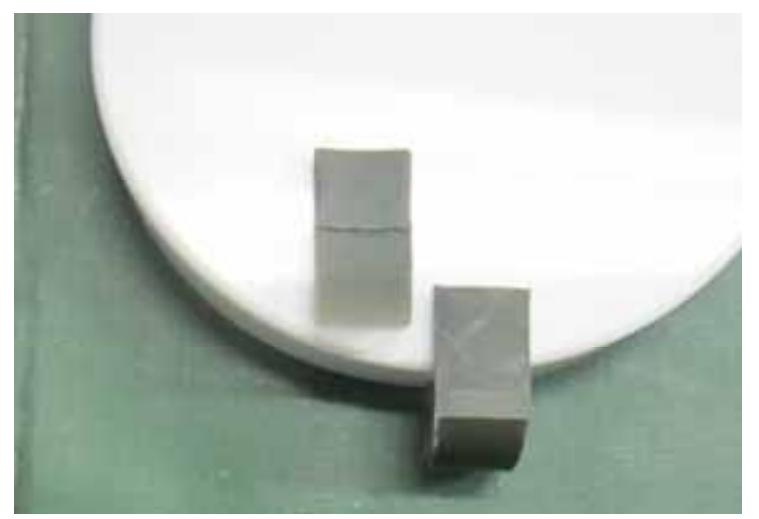

Figure 23. Parts of the specimen cut out from the assembly sealed with the system 3 , after tensile testing

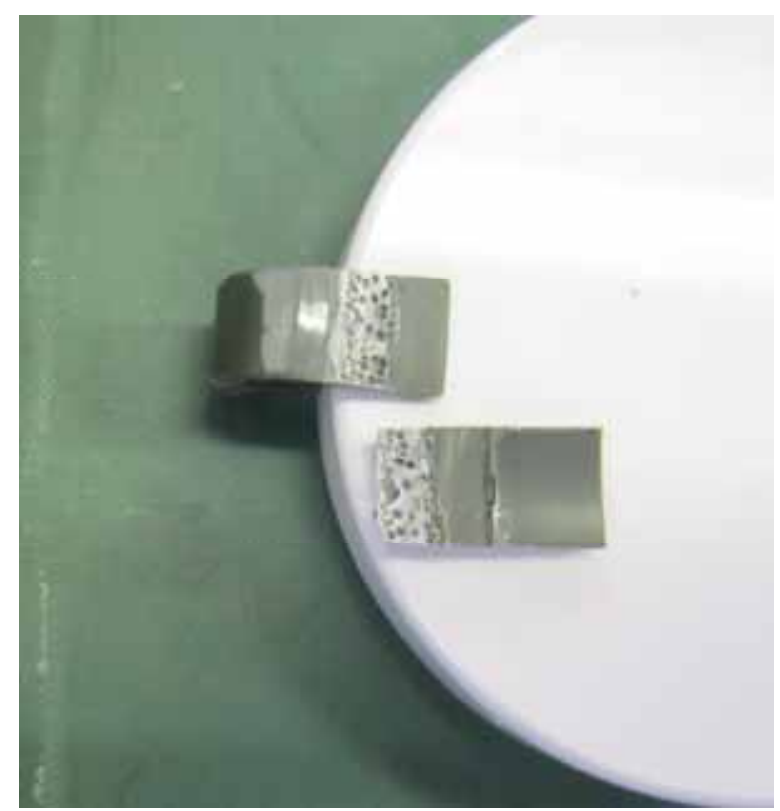

Figure 24. Parts of the specimen cut out from the assembly sealed with the system 4 , after tensile testing

By the detailed analysis of the specimens after tensile testing a cohesive splitting at the systems $1,2,3$ and 4 is recorded. This event is the proof that the adherent force between the sealing systems 1, 2, 3 and 4 (i.e. white silicone, black silicone, epoxy resin and polystyrene solution) and material, which has been sealed (polystyrene), is higher than the cohesive force of four mentioned systems.

On the separated surfaces of a specimen, cut out from the assemblies sealed with white silicone (Fig.21), black silicone (Fig.22) and epoxy resin (Fig.23), a homogeneity of all three applied systems is recorded.

On the separated surfaces of a specimen, cut out from the assembly sealed with the polystyrene solution (Fig.24), a porosity of the applied system is clearly visible.

\section{Conclusion}

Based on the presented details, one may conclude:

1. Sealing of the plastic polystyrene assemblies, exposed to the outer higher water pressure of $39,1 \mathrm{kPa}$ (immersion depth of $4 \mathrm{~m}$ ) and moderate water pressure of $9,78 \mathrm{kPa}$ (immersion depth of $1 \mathrm{~m}$ ) is done successfully.

2. Sealing is realized using the polystyrene parts (produced by injection molding of the high impact polystyrene trade mark Styron 485) and four sealing systems:

- specific white silicone of Dow Corning 744 trade mark, 
- black modified silicone of Permatex Black Silicone Adhesive Sealant trade mark,

- epoxy system, consisting of a modified epoxy resin of Araldite DBF trade mark and amine curing agent of Haerter 951 trade mark and

- solution of the high impact polystyrene of Styron 485 trade mark in toluene.

3. By the analysis of the indicator paper, which is inside the realized sealed plastic assemblies, and by the detailed visual inspection of the internal surfaces of upper and lower parts of the mentioned assemblies, it is established that water breakthrough did not happen.

4. All four applied sealing systems prevent water pass through the produced assemblies and protect the indicator paper inside the assemblies from the water influence.

5. The homogeneity of the applied sealing systems in the produced joints is tested.

6. It is established that white silicone (system 1), black silicone (system 2) and epoxy system (system 3) are homogenous in the produced joints, while at the joints with a polystyrene solution (system 4) a certain porosity is recorded.

7. The adhesion forces between all four sealant systems (even at polystyrene solution, which produced partially porous joints) and material, that is to be sealed (polystyrene) is higher than the cohesive energy of the applied systems.

8. Proper pre-treatment of the surfaces that are going to be sealed by a mechanical removing of the surface layer with the abrasive paper and degreasing and cleaning by the liquid chemical (ethanol) is important.

\section{References}

[1] ROSATO,D., ROSATO.M.G., ROSATO,D.V.: Concise Encyclopedia of Plastics, Kluwer Publishers, Norwell, 2000 ISBN 0-7923-8496-2.
[2] Adhesives and Sealants, Materials Engineering, May, 1976, pp.73-78.

[3] www.globalspec.com/.../high_pressure_plastic_container

[4] Continuous process for cooking food contained in hermetically sealed glass containers, US 3469988 A US patent..

[5] CHANDA,M., ROY,S.K.: Plastic Technology Handbook, CRC Press Taylor and Francis Group, Boca Raton, 2007, ISBN 13:978-08493-7039-7.

[6] RADULOVIĆ,J., JOVANČIĆ,S., DŽELEBDŽIĆ,N.: Injection Moulded Polycarbonate Covers of Rocket Launcher Tubes, Scientific Technical Review, ISSN 1820-0206, 2014, Vol.64, No.1, pp.55-61.

[7] MITTAL,K.L., PIZZI,A.: Handbook of Sealant Technology. CRC Press. pp.27. ISBN $0-8493-9162-8$, , (2009).

[8] ELIAS,H.G.: Introduction to Plastics, Wiley-VCH GmbH and Co.K Ga A, Weinheim, 2003.

[9] RADULOVIĆ,J.: Investigation of the influence of natural weathering factors on the properties of polyamide thermoplastic materials, ScientificTechnical Review, ISSN 1820-0206, 2005, Vol.LV, No.3-4, pp.21-28.

[10] http://www.sustainablefacilities.com/Sustainable_Facilities_\%_Infra structure_Lab/Theses+Dissertations_fi les/Shel1\%202008.pdf. http://www.styron.com/eu/en/products/plastics/poly_res.htm.

[11] http://www.krayden.com/tds/dow-744-tds.pdf.

[12] http://www.permatex.com/products-2/product-catego ries/adhesivessealants/sealants/permatex-black-silico ne-adhesive-sealant-detail.

[13] http:www.silmid.com/getattachement/8d2ddcd0-ad 60-41a8-bd6d3cdcdf462c29/ARALDITE-HY951-TDS.aspx.

[14] Der Loctite, Technical Information, Loctite G.m.b.H., Wiener Verlag, Himberg 1998.

[15] SRPS EN 60068-2-17, Basic environmental testing procedure - Part 2-17 : Tests- Test Q : Sealing, Institute for Standardization of Serbia, Belgrade, 2008.

[16] KOSTIĆ,A., VASIĆ,D., RADULOVIĆ,J.: Investigation of sealing of plastics parts assembly exposed to higher water pressure, $6^{\text {th }}$ International Scientific Conference on Defensive Technologies OTEH 2014, 09-10. October 2014, Belgrade, SERBIA, ISBN 97886-81123-71-3, Proceedings, pp. 796-801.

\title{
Ispitivanje uticaja spoljneg povišenog i umerenog vodenog pritiska na karakteristike zaptivenih termoplastičnih delova
}

\begin{abstract}
U ovom radu opisan je uticaj spoljneg visokog i umerenog vodenog pritiska na karakteristike zaptivenih spojeva termoplastičnih delova. Epruvete od polistirola otpornog na udar oznake Styron 485, četiri sistema za hermetizaciju i indikatorski papir, smešten unutar spojenih delova, korišćeni su za izradu pomenutih spojeva. Primenjeni su specifični silikonski materijal bele boje oznake Dow Corning, modifikovani silikonski materijal crne boje oznake Permateks, zalivna masa na bazi Araldite sistema modifikovane epoksi smole i aminskog očvršćivača i rastvor polistirola otpornog na udar oznake Styron 485 u toluenu. Proizvedeni spojevi su bili potopljeni u vodu na dubini od 4 metra (visok vodeni pritisak) i na dubini od 1 metar (umereni vodeni pritisak), u skladu sa standardom SRPS EN 60068-2-17. Na osnovu utvrđenog stanja indikatorskog papira i detaljnog pregleda delova tretiranih spojeva, konstatovano je da nije došlo do prodora vode i da su sva četiri primenjena sistema sprečila prolaz vode kroz zaptivene spojeve. Izvršeno je zatezno ispitivanje formiranih spojeva radi utvrđivanja homogenosti primenjenih zaptivnih materijala u pomenutim spojevima. Vizuelnim pregledom utvrđeno je da su beli silikon (sistem 1), crni silikon (sistem 2) i epoksi sistem (sistem 3) homogene strukture u spoju, dok je kod spojeva sa rastvorom polistirena (sistem 4) uočena blaga poroznost
\end{abstract}




\title{
Исследование влияния внешнего высокого и умеренного давлений воды на характеристики запечатаных частей из термопластиковых материалов
}

\begin{abstract}
В этой статье описано влияние внешнего высокого и умеренного давлений воды на особенности герметичных швов деталей из термопластиковых материалов. Пробирки из ударопрочного полистирола под символом STYRON 485, четыре системы наддува и индикаторная бумага, расположенная внутри соединяемых частей, были использованы для изготовления указанных выше соединений. Были применены удельный силиконовый материал белого цвета с названием Dow Corning, модифицированный силиконовый материал чёрного цвета с названием Permatex, текучая масса на основе Araldite системы модифицированной эпоксидной смолы и аминного отвердителя с раствором ударопрочного полистирола под символом STYRON 485 в Tолуоле. Полученные соединения были погружены в воду на глубину 4 метров (высокое давление воды) и в воду на глубине 1 метр (умеренное давление воды), в соответствии со стандартом СРПС ЕН 60068-2-17. На основании результатов и состоянии индикаторной бумаги и подробного осмотра частей обработанных соединений, был сделан вывод, что не было проникновения воды, и что все четыре прикладываемые системы предотвратили прохождение воды через герметичные соединения. Здесь выполнено тестирование напряжённости сформированных соединений для определения однородности прикладываемого уплотнительного материала в указанных соединениях. Визуальный осмотр показал, что белый силикон (система 1), чёрный силикон (система 2) и эпоксидная система (система 3) однородные структуры в соединении, а в то время в соединениях с раствором полистирола (система 4) наблюдалась умеренная пористость.
\end{abstract}

Ключевые слова: пластиковые материалы, структурные элементы, соединение, давление воды, герметики, однороднось соединения.

\section{Examen de l'influence de la haute et modérée pression extérieure de l'eau sur les caractéristiques des parties thermoplastiques hermétiques}

\begin{abstract}
Dans ce travail on déerit l'influence de la pression extérieure, haute et modérée, de l'eau sur les caractéristiques des joints des parties thermoplastiques. Les éprouvettes de polystyrène résistent au choc marqué Styron 485 , quatre systèmes pour le colmatage et le papier indicateur placé à l'intérieur des parties jointes ont été utilisés pour la fabrication des joints cités. On a utilisé le matériau spécifique de silicone blanc marqué Dau Korning, le matériau silicone noir modifié Permatex, masse de colmatage basée sur le système Araldite de la résine époxy modifiée et le durcisseur amine ainsi que la solution de polystyrène résistent au choc Styron $\mathbf{4 8 5}$ dans toluène. Les joints obtenus ont été immergés dans l'eau à la profondeur de 4 mètres (haute pression d'eau) et à la profondeur de 1 mètre (pression d'eau modérée) conformément à la norme SRPS EN 60068-2-17. A la base de l'état constaté chez le papier indicateur et après l'examen détaillé des parties des joints traités on a constaté que l'eau n'a pas pénétré et que tous les quatre systèmes appliqués ont empêché le passage de l'eau à travers les joints colmatés. On a effectué l'examen à la tension des joints colmatés pour étudier l'homogénéité des matériaux de colmatage utilisés pour les joints cités. Par l'examen visuel on a constaté que les silicones blancs (système 1), silicones noirs (système 2) et le système époxy (système 3) étaient les structures homogènes dans le joint alors que chez les joints à la solution de polystyrène (système 4) on a pu observer une légère porosité.
\end{abstract}

Mots clés: matériaux plastiques, éléments de construction, joint, pression d'eau, hermétiques, homogénéité de joint. 